\title{
School Violence Is Not Going Away So Proactive Steps Are Needed
}

Kylee Crews, (Email: Kylee.Crews@asu.edu), Arizona State University, Jack Crews, (Email: jack.crews@phoenix.edu), University of Phoenix Freda Turner, (Email: fturner@gcu.edu), Grand Canyon University

\begin{abstract}
Problems associated with school violence include higher than average teacher turnover, increased student dropout rates, students changing schools, and principals/teachers retiring early. There are 19 strategies offered that might reduce school violence.
\end{abstract}

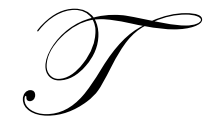

he start of school means students may be returning to a dangerous environment. The National Center for Education Statistics (2006) published that $5 \%$ of the nation's students reported being victims of some sort of violence at school. In 2005, 48 students died from school violence in America with 250,000 kids suffering serious injuries (Speaker, 2006). News accounts of violent incidences on school campuses include assaults, arson, kidnapping, use or possession of weapons, intimidation, harassment, bullying, mugging, threatening, theft, sexual offenses, bomb threats, disruptive incidences, use, sale or possession of drugs or alcohol, attacks on teachers, and murder. The April 20th, 1999 Columbine shootings where two students at a Colorado high school killed 13 people, injured 25 individuals, and then killed themselves, provided a wake-up call about school violence. In 2006 the news from Alaska reported the arrest of 12 year old boys accused of planning an assault shook the town. Some problems that result from school violence are presented below.

Problems associated with school violence include higher than average teacher turnover, increased student dropout rates, students changing schools, and principals/teachers retiring earlier than expected. Increases in violence on school property can make students depressed, scared, and anxious. Until students are comfortable in their environment learning will be minimal and less than what our society expects for our students successful future. Additionally those involved in violence are charged with battery and or murder in some cases. Witnessing fights at school makes it a difficult place to concentrate and learn. In some cases, the amount of time the teacher has to teach is lessened because teachers are busy trying to calm and control rowdy kids in and out of the classroom. The federal No Child Left Behind law requires districts to identify persistently dangerous schools. This has resulted in parents electing to exercise the option of transferring their children to another school. Some accounts have emerged where state officials have discovered educational leaders failing to report or under reporting offenses of violence on their campus. This lack of accurate reporting can lead to misinformed parents on the possible dangers to their child (ren) and may result in a less than desirable outcome. If we are at a point that our educational leaders must subscribe to unethical practices that may endanger their student body then we have a crisis on our hand that is monumental. This is not a one-dimensional issue, all aspects are affected in the school and in the community.

\section{WHAT CONTRIBUTES TO SCHOOL VIOLENCE?}

We simply cannot ignore the fact that violence is occurring in schools around the nation. It is essential to resolve this problem so that we direct young people to become productive and law-abiding citizens. School teachers and administrators are spending an increasingly large amount of time on preventing or minimizing the opportunities for violence to occur in the classroom or on the school campus. This time takes away from the academics and lessens the budget of our curricular materials. Schools are not funded adequately as it is and for more of the budget to go for violence prevention and less for student academic materials is a disastrous path for our public schools to take in this global competitive world for our students to enter at a disadvantage. Understanding factors that might contribute to school violence includes: 
1. School districts are under tremendous pressure to meet mandated test scores so budgets have been redirected from spending on school safety resources and staff-training programs that can help identify signs of violence or mental health issues among youths.

2. Children who cannot deal with being teased, intimidated or deliberately excluded tend to become violent.

3. Violent behavior may be desensitized and learned when children are exposed to violence on television, or observing behaviors, lifestyles and values of adults.

4. The inability to deal with feelings or displaced anger over events that occur in the homes can result in venting at school. Insecure children often develop violent behaviors.

5. Children have not been taught to respect teachers. Teachers should be considered a figurehead of respect.

6. There are too few school police officers, a need for stricter enforcement of rules, and more involvement from parents.

7. As failing schools are identified and closed, the students are moved to other schools. This creates groups vying for dominance. In some cases, if gang lines are crossed, there is more conflict.

8. A series of video games has U.S. education officials questioning the possible negative impact of graphic depictions of schoolyard violence. The Miami Herald reported in March 2006 that the Miami-Dade school district in Florida was preparing to fight the release of the video game, Bully. This game is built entirely around bullies and depicts school yard violence (Hearn, 2006). Grand Theft Auto game has been questioned by educators as a negative influence on young school-age players. Marc Ecko's Getting Up: Contents Under Pressure was denied classification by the Australian Government's Classification Review Board on the basis that playing the game could promote or incite a crime.

9. Some music lyrics promote violence. For example, one song contains the following lyrics "gonna get my gat (gun) . . . gonna shoot up my school, gonna kill me a pig, all before I go to bed tonight" (Reynolds, 2006).

10. There are sites on the Internet that where kids can collaborate with others relating to violence and even how to make school bombs.

11. Dress codes should be published to discourage school violence. For example, the wearing of certain pieces of clothing like a bandana identifies the wearer as a member of specific gangs. Executive director of the National School Safety Center published,

1. "There is a clear and definitive evidence there is a correlation between violence and school dress codes" Schools that have standardized student clothing have reported reduced gang problems" (Jun, 2006).

12. Hate-related graffiti and racial tensions contribute to violence.

13. Bullying is problematic and contributes to school violence. Bullycide is a new term that refers to killing of another student/person due to being bullied or the bully victim feeling hopeless to the point of revenge or suicide. The 1972 song, Lunchbox is a fictional account referring to bullying and thus the banning of metal lunchboxes on campus. A novel, Rage, provides a story of a teen after being abused and bullied by his father goes insane and takes a class of 24 student's hostage and kills two teachers.

14. Text message bullying by phone and websites is a form of abuse that can lead to violence.

15. Transferring students from schools that have failed to meet state academic standards to other schools creates an overcrowding problem and increase in violence.

\section{STRATEGIES EDUCATORS CAN TAKE TO DECREASE THE LIKELIHOOD OF SUCH SCHOOL VIOLENCE}

Educational leaders need to do more than just release lists of persistently dangerous" schools, point fingers, and focus the blame on others. Yes, the $\$ 100$ million funding loss from the Department of Education's Office of Safe and Drug-Free Schools has had a negative impact on funding to support the reduction of school violence. However, the following measures might help curb school violence and should be considered.

1. Create an awareness that the progression of violence-related problems at school seems to be in the following order: angry language, harassment, and then violence. Students should be taught that on the onset of name calling to say that is not funny and walk away. 
2. Break down barriers between groups starting in elementary educational environments by pairing up children with someone they do not know and have them introduce the new person to get to know and be comfortable with people who are different.

3. Encourage students to create anti-violence leadership clubs/programs and conflict mediation programs to develop/improve student leadership and creative thinking skills.

4. School officials should create awareness that school violence will not be tolerated. Create news when events occur involving vandalizing, cheating, fights, arson, or weapons found on campus to heighten awareness that this will not be tolerated. Many acts of violence are committed to impress friends - make this a non-issue.

5. School officials must act quickly to involve law enforcement relating to any suspicious student activities if they perceive the threat of violence.

6. Schools leaders must approach every perceived threat, joke about violence or other indication of violence, just as airport screeners do.

7. $\quad$ Create a tipster program for students to report potential dangers before they happen. Make available a 1800 number or anonymous drop box.

8. Provide training to enhance social and conflict-resolution skills to all students and especially victims of school-yard harassment. Teach assertiveness skills to individuals at high risk of becoming targets.

9. Educate teachers and students on how deal with hate crime threats and incidences.

10. Do not allow negative music that contains language of lawlessness on school campuses.

11. Schools leaders on the national/district level should keep accurate records by school of violent and disruptive incidences to determine which schools should be designated as persistently dangerous. It is estimated that one-third of on-campus incidents are not reported (Office of the New York State Comptroller, 2005), therefore, site visits should be conducted and principals should be required to confirm accuracy in reporting. Parents are allowed by law to transfer their children out of schools on the persistently dangerous schools list, therefore, educational leaders try to avoid this list vice putting strategies in place to minimum repeat of problems.

12. Educational leaders should develop a tiger team of parents, students, and faculty to prepare an Incident Reduction Plan for each school.

13. Educate parents on the hazards of video games that involve violence. The focus of some video games is to blow off a virtual playmate's heads off and the reward is points in the game. This desensitizes young children to violence.

14. Provide workshops and seminars on the prevention of bullying, intimidation, and harassment.

15. Implement parenting classes and how the community might unite to reduce school violence.

16. Upgrade surveillance cameras in halls, dining rooms and bath rooms. Off-duty police officers should be added, and have special school climate teams handle flare-ups that could lead to violence.

17. Build stronger relationships between school officials, activities, and the police department. Hire retired or off-duty police officers during early morning and late evening hours when violence tends to be the highest.

18. Create alternative schools for children to help minimize the problem.

19. Look for signs of angry, disgruntled or 'loner' students. According to a 2002 study by the Secret Service National Threat Assessment Center and the Safe and Drug-Free Schools Program, there were 37 incidents involving 41 school attacks that had occurred between 1974 and 2000, most attackers displayed pre-attack behavior that can signal a potential for violence" (Lewin, 2006). Garbarino, author of books on youth violence published that "one in five \{students) are so troubled they need professional intervention (2000, p. $33)$.

\section{CONCLUSION}

School violence is not just a school problem but a larger societal issue that requires efforts of students, parents, faculty, and the community. Everyone is affected from those on fixed incomes to those that are running large businesses to governmental infrastructures in every community. Although many would like to isolate the problem to the public schools because of the ease of this target, we must all shoulder the responsibility of minimizing this dilemma that affects the future of our country. Education is important to a nation. Civilizations with a highly educated workforce experiences higher economic and living conditions than societies with less educated 
citizenries, therefore, this problem needs a focused leadership effort to provide our children with an education to keep this nation competitive.

\section{REFERENCES}

1. Garbarino, J. (2000). Lost boys: why our sons turn violent and how we can save them. New York: Anchor Books.

2. Hearn, P. (2006, March 15). Scrap looms over Bully game. Retrieved on March 16, 2006, from http://www.smh.com.au/news/breaking/scrap-looms-over-bully-game/2006/03/15/1142098512021.html

3. Jun, C. (2006, May 13). Rules a challenge for principals. Retrieved on May 15, 2006, from detnews.com http://www.trinidadexpress.com/index.pl/article news?id=135612602

4. Lewin, A. M. (2006, April 26). Are Schools Safer Post-Columbine? Retrieved on April 26, 2006, from http://abcnews.go.com/US/story?id=1883687\&page=1

5. Office of the New York State Comptroller. (2005). Reporting of Violent and disruptive incidents in schools. Retrieved on May 25, 2006, from www.osc.state.ny.us/audits/

6. Reynolds, E. (2006, May 14). Pay attention to what your kids see and do. Retrieved on May 16, 2006, from http://www.azcentral.com/arizonarepublic/viewpoints/articles/0514reynolds0714.html

7. Speaker Helps Educators Address School Violence (2006, April). WLUC-TV - Negaunee, Michigan. Retrieved on April 30,2006, from http://www.wluctv6.com/Global/story.asp?S=4826102\&nav=81AX

8. The National Center for Education Statistics. (2006). School violence. Retrieved September 3, 2006, from http://nces.ed.gov/programs/quarterly/vol 5/5-4/3 5.asp

\section{NOTES}

